\title{
Knowledge, Attitude, and Practice Regarding Coronavirus Disease-19: Population-Based Study in Iraq
}

\author{
Hasanain Faisal Ghazi ${ }^{1 *}$, Taqi Mohammed Jwad Taher ${ }^{2}$, Mohammed A. AbdalQader ${ }^{1}$, Rana Hussein Raheema ${ }^{3}$, \\ Mohammed Faez Baobaid ${ }^{1}$, Tiba Nezar Hasan ${ }^{1}$ \\ ${ }^{1}$ Department of Community Medicine, International Medical School, Management and Science University, Selangor, Malaysia; \\ ${ }^{2}$ Department of Community Medicine, College of Medicine, University of Wasit, Iraq; ${ }^{3}$ Department of Microbiology, College of \\ Medicine, University of Wasit, Iraq
}

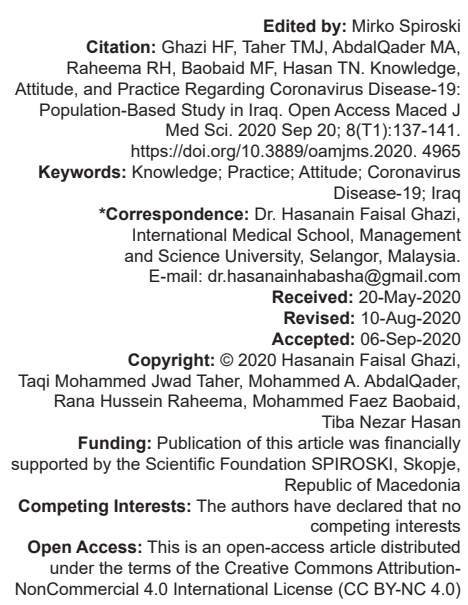

Edited by: Mirko Spiroski Edited by: Mirko Spirosk
Citation: Ghazi HF, Taher TMJ, AbdalQader MA Citation: Ghazi HF, Taher TMJ, AbdalQader MA,
Raheema RH, Baobaid MF, Hasan TN. Knowledge Raheema RH, Baobaid MF, Hasan TN. Knowledge,
Attitude, and Practice Regarding Coronavirus Disease-19: Population-Based Study in Iraq. Open Access Maced J Med Sci. 2020 Sep 20; 8(T1):137-141.
https://doi.org/10.3889/oamjms.2020. 4965 Keywords: Knowledge; Practice; Attitude; Coronavirus Disease-19; Iraq
*Correspondence: Dr. Hasanain Faisal Ghazi International Medical School, Management and Science University, Selangor, Malaysia. E-mail: dr.hasanainhabasha@gmail.com Received: 20-May-2020 Revised: 10 -Aug-2020
Accepted: 06-Sep-2020 Copyright: ๑ 2020 Hasanain Faisal Ghazi, Taqi Mohammed Jwad Taher, Mohammed A. AbdalQader Rana Hussein Raheema, Mohammed Faez Baobaid,

Tiba Nezar Hasan Funding: Publication of this article was financially supported by the Scientific Foundation SPIROSKI, Skopje. Competing Interests: The authors have declared that no Open Access: This is an open-access article distributed under the terms of the Creative Commons AtributionNonCommercial 4.0 International License (CC BY-NC 4.0)

\begin{abstract}
INTRODUCTION: In March 2020, the world health organization declared Coronavirus Disease (COVID)-19 a pandemic global communicable disease, there is neither a vaccine nor a treatment for this virus. The aim of the current study was to assess knowledge, attitude, and practice (KAP) of Iraqi population toward COVID-19.

METHODS: A cross-sectional study was conducted among 272 respondents from different states of Iraq using online administered questionnaires. The questions were adopted from the previous study and consist of three parts mainly socio-demographic, KAP.

RESULTS: The majority of the respondents had good knowledge regarding COVID-19 (95.2\%). A total of $97.8 \%$ of the respondents knew that COVID-19 caused by a virus. Regarding incubation period, $75 \%$ of them answer correctly that it is $2-15$ days. Higher percept (39\%) and $37.9 \%$ of participant people considered the disease as a very dangerous and seriously dangerous disease, respectively. The majority $(85.3 \%)$ of the sample thought that no vaccination available for the disease. More than two-thirds of the sample $(76.5 \%)$ were wearing face mask sometimes while only $19.5 \%$ wearing it all the time. The majority (265) out of 272 was ready to stay home if it required to prevent the spread of the disease. There was a significant association between gender, living state, and COVID-19 knowledge $(p=0.009,<0.0001)$, respectively.
\end{abstract}

CONCLUSION: The overall knowledge, practice of respondents was good regarding COVID-19. People need to stay at home to prevent the infection and reduce the number of cases.

\section{Introduction}

The new epidemic virus infection 2019-novel coronavirus (nCoV) (now named Severe acute respiratory syndrome [SARS]-CoV-2) that rise in china with about tens of thousands of people infected give worldwide attention and response as it infects people in about 28 countries [1]. The first record of this nCoV was in Wuhan, China, at the end of 2019 [2]. This virus is belonging to a large family of viruses that can infect a wide range of organisms such as birds and mammals, including humans, according to the world health organization (WHO) [3].

For its more pronounce symptom, the new diseases are called the SARS-CoV-2 [4], [5]. The features of the nCoV (2019-nCoV) are summarized as a positive-sense single-stranded RNA virus mainly with respiratory illness. Hence, the new SARS-CoV-2 disease is a contagious in humans it gets attention and the WHO announced it as an ongoing pandemic disease with public health emergency of international concern [6], [7].
Each infection results in 1.4-3.9 new cases according to epidemiological studies when there is no immune previously done and no preventive measures are taken. The primary route of infection of this virus appears related to close contact with infected people and through coughs or sneezes which release a respiratory droplet [8]. After contact, the virus starts to invade the human cells by binding to the angiotensinconverting enzyme receptor 2 [9].

In Iraq, the first CoV disease (COVID)-19 cases was discovered in February 2020. As of August 1,2020 , there are 126,704 confirmed cases with 4805 deaths [10].

No approved SARS-CoV-2 therapy or vaccine is currently available. Primary step to reduce the spread of the virus both in health-care settings and the population is to introduce effective infection controls [11]. Public awareness of the treatment of highly infectious respiratory diseases plays a key role in limiting infection spread, especially in middle and low revenue countries, where health systems at best have moderate capacity to respond to outbreaks. Egypt had over 800 confirmed 
cases by the beginning of April 2020 and over 50 deaths, with a fast growth trend [12]. The development of vaccines is estimated to take months, and so crisis management mainly depends on adherence of people to the measures recommended. The awareness, perceptions, and behaviors (knowledge, attitude, and practice) of the public have a significant impact on these measures [13].

The aim of the current study was to find out the level of knowledge and practice about COVID-19 among general population in Iraq.

\section{Methods}

A cross-sectional study was conducted among 272 adults living in Iraq using internet-based platform. The respondents were chosen using non-probability convenience sampling. The questionnaires link was distributed to respondents through Facebook groups and a Google form was used to host and distribute the questions. After accessing the link, respondent needs to read the consent form carefully and agrees to participate in the study. A full explanation of the study aims, and objectives were written in the introduction part of the questionnaires. All the questionnaires are compulsory to answer. The questionnaires consist of three parts, Part 1 about socio-demographic data (age, gender, educational level, working status, and state), Part 2 about COVID-19 knowledge (transmission method, treatment availability, incubation period, and patient presentation), and Part 3 about practice and attitudes toward COVID-19 (hand washing, hand sanitizer, and home quarantine). The questionnaires were adopted from the previous study [14].

Knowledge questionnaires consist of seven questions and maximum score of 7 . Those who answered more than $50 \%$ considered to have good knowledge.

The sample size was calculated based on the previous study [13] where good knowledge was $90 \%$ and using single population proportion formula.

$\mathrm{N}=1.96^{2} \times\left(0.90(1-0.90) / 0.05^{2}\right)=139+20 \%$ non-response rate $=167$ the minimum sample size required.

We decided to use internet-based method in data collection due movement restriction and curfew imposed by Iraqi government on March 17, 2020, that make it difficult to use physical data collection methods and also to decrease the contact between people to minimum as much as possible.

Data were analyzed using SPSS software version 24. All respondents filled up a consent form and agreed to participate in the study before proceeding to the questionnaires and ethical approval was taken from International Medical School, Management and Science University.

\section{Results}

Table 1 demonstrates the socio-demographic features of the study participants. The mean age for the 272 respondents was $36.35 \pm 7.87$, with more than half of them $(58.1 \%)$ were males. Only nine states were involved in answering the survey questions, with a higher percentage in Baghdad city which represents about $182(66.9 \%)$ of the whole sample, followed by 37 persons $(13.65 \%)$ were from Basra city. The majority $(87.5 \%)$ of the sample were working at the same period of data collection with $202(74.3 \%)$ of them had postgraduate educational level. The internet and different social media such as Facebook and Instagram were the major source of information about COVID19 in $130(47.8 \%)$ of the sample, followed by medical doctors in about 30 (25.8\%) of the participants. Only 9 $(3.3 \%)$ of the sample were mentioned as a relative to positive COVID-19 test patients.

Table 1: Socio-demographic characteristics of the respondents

\begin{tabular}{|c|c|c|c|c|}
\hline Variables & Min. & Max. & Mean & SD \\
\hline \multirow[t]{2}{*}{ Age } & 23.0 & 65.0 & 36.35 & 7.87 \\
\hline & $\mathrm{N}$ & & $\%$ & \\
\hline \multicolumn{5}{|l|}{ Gender } \\
\hline Male & 158 & & 58.1 & \\
\hline Female & 114 & & 41.9 & \\
\hline \multicolumn{5}{|l|}{ State } \\
\hline Erbil & 6 & & 2.2 & \\
\hline Basra & 37 & & 13.6 & \\
\hline Sulaymaniyah & 7 & & 2.6 & \\
\hline Mosul & 7 & & 2.6 & \\
\hline Baghdad & 182 & & 66.9 & \\
\hline Diyala & 6 & & 2.2 & \\
\hline Dhi Qar & 5 & & 1.8 & \\
\hline Kirkuk & 2 & & 0.7 & \\
\hline Wasit & 20 & & 7.4 & \\
\hline \multicolumn{5}{|l|}{ Currently Working } \\
\hline No & 34 & & 12.5 & \\
\hline Yes & 238 & & 87.5 & \\
\hline \multicolumn{5}{|l|}{ Educational level } \\
\hline Secondary & 4 & & 1.5 & \\
\hline University degree & 66 & & 24.2 & \\
\hline Postgraduate & 202 & & 74.3 & \\
\hline \multicolumn{5}{|l|}{ Source of information } \\
\hline Television & 49 & & 18.0 & \\
\hline Internet (Facebook, WhatsApp, Instagram) & 130 & & 47.8 & \\
\hline Medical doctors & 70 & & 25.8 & \\
\hline Radio & 23 & & 8.4 & \\
\hline \multicolumn{5}{|l|}{ Relatives with COVID-19 } \\
\hline No & 263 & & 96.7 & \\
\hline Yes & 9 & & 3.3 & \\
\hline
\end{tabular}

Table 2 shows the knowledge of respondents about COVID-19. Most of the sample 266 (97.8\%) were aware of the nature of the disease and agreed with the answer (virus) as a cause of the disease. In this study, 250 respondents (91.9\%) mentioned infected persons who transmit the disease, while only $15(5.56 \%)$ were mentioned Bats. Two-thirds of the sample $(75 \%)$ were informed about the true incubation period of COVID-19. Most of the study participants $(83.82 \%)$ knew that washing hands can be an effective preventive method for the disease rather than covering face while sneezing and vaccination. About patients' 
Table 2: Knowledge on COVID-19 among respondents

\begin{tabular}{ll}
\hline Knowledge & $\mathrm{n}(\%)$ \\
\hline COVID-19 caused by & \\
Virus & $266(97.8)$ \\
I do not know & $6(2.2)$ \\
COVID-19 transmitted by & \\
$\quad$ Camel & $7(2.6)$ \\
Bats & $15(5.56)$ \\
Infected person & $250(91.9)$ \\
COVID-19 Incubation period & \\
$2-10$ days & $25(9.2)$ \\
$2-20$ days & $33(12.1)$ \\
$2-15$ days & $204(75.0)$ \\
I do not know & $10(3.7)$ \\
Patient presentation & \\
Sore throat, vomiting and diarrhea & $19(6.99)$ \\
Fever and body ache & $48(17.65)$ \\
I do not know & $3(1.10)$ \\
Lower respiratory syndrome (cough and shortness of breath) & $183(67.28)$ \\
Upper respiratory syndrome (Runny nose, Sore throat) & $19(6.99)$ \\
Prevention possible through & \\
Vaccine & $6(2.21)$ \\
Cover face when sneezing & $27(9.93)$ \\
Wash hands regularly & $228(83.82)$ \\
No method for prevention & $11(4.04)$ \\
COVID-19 treatment & \\
Supportive at home & $91(33.46)$ \\
At hospitals & $70(25.74)$ \\
ICU & $23(8.46)$ \\
No treatments & $88(32.35)$ \\
Most affected areas in the world & \\
China & $257(94.49)$ \\
Iraq & $2(0.74)$ \\
USA & $13(4.78)$ \\
\hline
\end{tabular}

presentations, 183 (67.28\%) persons mentioned lower respiratory symptoms. It was obvious for $257(94.49 \%)$ participants that China is the most affected area in the world. About $33.46 \%$ and $32.35 \%$ answered the using of a supportive treatment at home and no treatment, respectively, for the treatment of this disease.

In Table 3, about $80.2 \%$ of participants mentioned that COVID-19 is a contagious disease and can lead to death, higher percept (39\%) and $(37.9 \%)$ of participant people considered the disease as a very dangerous and seriously dangerous disease, respectively. The majority $(85.3 \%)$ of the sample thought that no vaccination available for the disease. Regarding the practices performed by the respondents toward COVID-19, Table 3 shows more than that

Table 3: Attitudes and practice regarding COVID-19

\begin{tabular}{ll}
\hline Attitude & $\mathrm{n}(\%)$ \\
\hline I think COVID-19 is & \\
Contagious and cannot lead to death & $54(19.8)$ \\
Contagious and can lead to death & $218(80.2)$ \\
I feel COVID-19 is dangerous & \\
Dangerous & $56(20.6)$ \\
Very dangerous & $106(39.0)$ \\
Seriously dangerous & $103(37.9)$ \\
Not dangerous & $7(2.6)$ \\
There is vaccine for COVID-19 & \\
No & $232(85.3)$ \\
Yes & $17(6.2)$ \\
I do not know & $23(8.5)$ \\
I wear face Mask & \\
Sometimes & $208(76.5)$ \\
All the times & $53(19.5)$ \\
No benefit & $11(4.0)$ \\
I wear gloves & $184(67.7)$ \\
Sometimes & $81(29.8)$ \\
All the times & $7(2.5)$ \\
No benefit & \\
I wash my hands & $136(50.0)$ \\
More than 10 times/day & $125(45.0)$ \\
More than 3 times/day & $11(4.1)$ \\
1-2 times/day & \\
I use hand sanitizer & $63(23.2)$ \\
No & $209(76.8)$ \\
Yes & $7(2.6)$ \\
I will stay at home if require & $265(97.4)$ \\
No & \\
Yes &
\end{tabular}

two-thirds of the sample $(76.5 \%)$ were wearing face mask sometimes while only $19.5 \%$ wearing it all the time. About a third $(29.8 \%)$ wears gloves all the time. Very little percent $(4.1 \%)$ were washing hands $<3$ times/ day, while the majority $(76.8 \%)$ using hand sanitizer. As mentioned above, the majority 265 out of 272 was ready to stay home if it required to prevent the spread of the disease.

Table 4 demonstrates the association between socio-demographic characteristics and COVID19 knowledge, there was a significant association between gender, living state, and COVID-19 knowledge $(p=0.009,<0.0001)$ respectively.

\begin{tabular}{|c|c|c|c|c|}
\hline \multirow[t]{2}{*}{ Variables } & \multicolumn{2}{|l|}{ Knowledge } & \multirow[t]{2}{*}{$x^{2}$} & \multirow[t]{2}{*}{ p-value } \\
\hline & $\begin{array}{l}\text { Poor } \\
\mathrm{n}(\%)\end{array}$ & $\begin{array}{l}\text { Good } \\
\mathrm{n}(\%)\end{array}$ & & \\
\hline \multicolumn{5}{|l|}{ Gender } \\
\hline Female & $1(0.9)$ & $113(99.1)$ & \multirow[t]{2}{*}{6.56} & \multirow[t]{2}{*}{$0.009^{\mathrm{a}}$} \\
\hline Male & $12(7.6)$ & $146(92.4)$ & & \\
\hline \multicolumn{5}{|l|}{ Working Status } \\
\hline No & $0(0)$ & $34(100.0)$ & \multirow[t]{2}{*}{1.95} & \multirow[t]{2}{*}{$0.163^{a}$} \\
\hline Yes & $13(5.5)$ & 225 (94.5) & & \\
\hline \multicolumn{5}{|l|}{ Educational level } \\
\hline Secondary & $0(0)$ & $4(100.0)$ & \multirow[t]{3}{*}{5.16} & \multirow[t]{3}{*}{$0.076^{b}$} \\
\hline University & $0(0)$ & $66(100.0)$ & & \\
\hline Postgraduate & $13(6.4)$ & $189(93.6)$ & & \\
\hline \multicolumn{5}{|l|}{ Living states } \\
\hline Erbil & $6(100.0)$ & $0(0)$ & \multirow[t]{9}{*}{124.10} & \multirow[t]{9}{*}{$<0.001^{b}$} \\
\hline Basra & $0(0)$ & $37(100.0)$ & & \\
\hline Sulaymaniyah & $0(0)$ & $7(100.0)$ & & \\
\hline Mosul & $0(0)$ & $7(100.0)$ & & \\
\hline Baghdad & $7(3.8)$ & 175 (96.2) & & \\
\hline Diyala & $0(0)$ & $6(100.0)$ & & \\
\hline Dhi Qar & $0(0)$ & $5(100.0)$ & & \\
\hline Kirkuk & $0(0)$ & $2(100.0)$ & & \\
\hline Wasit & $0(0)$ & $20(100.0)$ & & \\
\hline
\end{tabular}

\section{Discussion}

Our findings suggest that general population in Iraq have good knowledge regarding COVID-19 with good level of practice just few weeks into the global pandemic announced by the WHO of COVID-19 and after declared public health emergency of international concern.

The level of good knowledge in our study was $95.2 \%$ which is similar to previous studies done [13]. Regarding the source of information, overall, the internet and social media (Facebook, WhatsApp, and Instagram) account for the main source of information of $47.8 \%$ of all other sources, second highest from medical personnel of $25.8 \%$ and least through radio $8.4 \%$ and that is persistent with another study done in China in year 2020 which found that the internet $(93.5 \%)$ was the primary health information channel for the general public during the initial stage of COVID-19 epidemic in China [15].

In this study, it was found that the level of knowledge was good overall the major parameters of knowledge and as compared to other study done in mainland China in 2020 it was similar result to us such 
as COVID-19 knowledge where respondents indicate that droplets $(92.1 \%)$, infected artifacts $(73.7 \%)$, and airborne transmission (60.5\%) are the most frequently seen transmission path. Nearly all respondents learned of an increase in infected people (98.8\%), an increase in deaths $(97.8 \%)$ and an increase in the number of persons recovered (93.3\%). The Web was the most popular source of health information on COVID-19 (93.5\%). The majority, $75.1 \%$, were very satisfied with the quantity of available health data [15].

This study showed high knowledge about the transmission mode through infected person $91.9 \%$ and that is consistent with the finding of other study which stated human-to-human transmittances for COVID-19 are well-established, with the $\mathrm{WHO}$ at present estimated to be 1.4-2.5 for R0 (expected number of secondary cases produced by a single typical) infected population [16].

The present study showed that the respondents had a strong understanding of the Cause-Inductor for the COVID-19, which was the $97.8 \% \mathrm{CoV}$, and this was similar to the international findings that a novel betaCoV now called SARS-CoV-2 causing clinical disease called COVID-19. SARS-CoV-2 shares 79\% SARS-CoV sequence identity, which resulted in a major outbreak in 2002-2003 [17], [18], [19].

The respondent's knowledge about the clinical symptoms was mainly toward the lower respiratory syndrome $(67.28 \%)$ for cough and shortness of breath, and next mentioned fever and body ache (17.65\%), and $1.1 \%$ stated they know nothing about the symptoms. A research was done in the United Kingdom (UK) mentioned that the most common symptoms being reported are fever, cough or chest tightness, and dyspnea, also added that cases are reported to experience a mild illness course [20].

Another research in the UK found fever (98\%), cough (76 \%), dyspnea (55\%), and myalgia or weakness $(44 \%)$ to be the most common signs of disease launch. Not least of all, few patients had strong signs of the upper airway tract like coryza and only one patient had diarrhea. Other clinical characteristics include development of sputum (28\%), headache $(8 \%)$, and hemoptysis in two cases [21].

This study has several limitations. Given the limited resources available and time-sensitivity of the COVID-19 outbreak that forced the authors to collect the data virtually through online questionnaires. Bigger study with more participants is needed also need to measure the impact of home stay on people's daily life.

\section{Conclusion}

The overall knowledge, practice of respondents was good regarding COVID-19. People need to stay at home and follow the health authorities' instructions to prevent the infection and reduce the number of cases.

\section{References}

1. Zhang $\mathrm{Y}$, Odiwuor $\mathrm{N}$, Xiong J, Sun L, Nyaruaba RO, Wei $\mathrm{H}$, et al. Rapid molecular detection of SARS-CoV-2 (COVID-19) virus RNA using colorimetric LAMP. MedRxiv. 2020. https://doi. org/10.1101/2020.02.26.20028373.

2. Unhale S, Ansar QB, Sanap S, Thakhre S, Wadatkar S, Bairagi $R$, et al. A review on corona virus (COVID-19). WJPLS. 2020;6(4):109-11.

3. World Health Organization. Coronavirus Disease (COVID2019) Situation Reports; 2020. Available from: https://www.who. int/emergencies/diseases/novel-coronavirus-2019/situationreports. [Last accessed on 2020 Mar 27].

4. Gorbalenya AE, Baker SC, Baric RS, de Groot RJ, Drosten C, Gulyaeva AA, et al. The species severe acute respiratory syndrome-related coronavirus: Classifying 2019-nCoV and naming it SARS-CoV-2. Nat Microbiol. 2020;5(4):536-44. https:// doi.org/10.1038/s41564-020-0695-Z

5. Centers for Disease Control and Prevention $(C D C)$. Healthcare Professionals: Frequently Asked Questions and Answers; 2020. Available from: https://stacks.cdc.gov/view/cdc/85912. [Last accessed on 2020 Mar 15].

6. Wee SL, McNeil DG Jr., Hernández JC. WHO Declares Global Emergency as Wuhan Coronavirus Spreads. The New York Times; 2020. Available from: https://www.nytimes. com/2020/01/30/health/coronavirus-world-health-organization. html. [Last accessed on 2020 Jan 30].

7. Chan JF, Yuan S, Kok KH, To KK, Chu H, Yang J, et al. A familial cluster of pneumonia associated with the 2019 novel coronavirus indicating person-to-person transmission: A study of a family cluster. Lancet. 2020;395(10223):514-23. https://doi. org/10.1016/s0140-6736(20)30154-9

8. Centre for Disease Control and Prevention (CDC). How COVID19 Spreads; 2020. Available from: https://www.cdc.gov/media/ releases/2020/s0522-cdc-updates-covid-transmission.html. [Last accessed on $2020 \mathrm{Jul} 25$ ]

9. Hoffman M, Kliene-Weber H, Krüger N, Herrler T, Erichsen S, Schiergens TS, et al. SARS-CoV-2 cell entry depends on ACE2 and TMPRSS2 and is blocked by a clinically proven protease inhibitor. Cell. 2020;181(2):10. https://doi.org/10.1016/j. cell.2020.02.052

PMid:32142651

10. Ministry of Heath Iraq, Daily Data on COVID-19 in Iraq. Available from: https://www.moh.gov.iq. [Last accessed on 2020 May 01].

11. Li JY, You Z, Wang Q, Zhou ZJ, Qiu Y, Luo R, et al. The epidemic of 2019-novel-coronavirus (2019-nCoV) pneumonia and insights for emerging infectious diseases in the future. Microb Infect. 2020;22(2):80-5. https://doi.org/10.1016/j.micinf.2020.02.002 PMid:32087334

12. Egypitan PM. Egypt's Coronavirus Figures Still Within Range; 2020. Available from: https://www.egypttoday.com/ Article/2/83291/PM-Egypt\%E2\%80\%99s-coronavirus-figuresstill-within-range. [Last accessed on 2020 Apr 17].

13. Zhong BL, Luo W, Li HM, Zhang QQ, Liu XG, Li WT, et al. Knowledge, attitudes, and practices towards COVID-19 among Chinese residents during the rapid rise period of the COVID-19 outbreak: A quick online cross-sectional survey. Int J Biol Sci. 2020;16(10):1745-52. https://doi.org/10.7150/ijbs.45221

PMid:32226294 
14. Nooh $\mathrm{HZ}$, Alshammary $\mathrm{RH}$, Alenezy JM, Alrowaili $\mathrm{NH}$, Alsharari AJ, Alenzi NM, et al. Public awareness of coronavirus in Al-Jouf region, Saudi Arabia. J Public Health. 2020;2020:1-8. https:// doi.org/10.1007/s10389-020-01209-y

\section{PMid:32206545}

15. Wang C, Pan R, Wan X, Tan Y, Xu L, Ho CS, Ho RC. Immediate psychological responses and associated factors during the initial stage of the 2019 coronavirus disease (COVID-19) epidemic among the general population in China. Int J Environ Res Public Health. 2020;17(5):1729. https://doi.org/10.3390/ ijerph17051729

16. Phan LT, Nguyen TV, Luong QC, Nguyen TV, Nguyen HT, Le HQ, et al. Importation and human-to-human transmission of a novel coronavirus in Vietnam. N Engl J Med 2020;382(9):872-4. PMid:31991079

17. Wu F, Zhao S, Yu B, Chen YM, Wang W, Hu Y, et al. Complete genome characterisation of a novel coronavirus associated with severe human respiratory disease in Wuhan, China. BioRxiv. 2020;2020:919183. https://doi.org/10.1101/2020.01.24.919183
18. Zhou $\mathrm{P}$, Yang $\mathrm{XL}$, Wang $\mathrm{XG}$, Hu B, Zhang L, Zhang $\mathrm{W}$, et al. Discovery of a novel coronavirus associated with the recent pneumonia outbreak in humans and its potential bat origin. BioRxiv. 2020;2020:914952. https://doi. org/10.1101/2020.01.22.914952

19. Lu R, Zhao X, Li J. Genomic characterisation and epidemiology of 2019 novel coronavirus: Implications for virus origins and receptor binding. Lancet. 2020;395:565-574. https://doi. org/10.1016/ S0140-6736(20)30251-8

20. Department of Health and Social Care, Public Health England Coronavirus: Latest Information and Advice; 2020. Available from: http://www.gov.uk/guidance/ wuhan-novel-coronavirus-information-for-the-public. [Last accessed on $2020 \mathrm{Apr}$ 01]. https://www.gov.uk/guidance/ coronavirus-covid-19-information-for-the-public.

21. Lake MA. What we know so far: COVID-19 current clinical knowledge and research. Clin Med (Lond). 2020;20(2):124-7. https://doi.org/10.7861/clinmed.2019-coron

PMid:32139372 